\title{
Um Convite a sonhar: a influência de Richard Shaull na formação do pensamento de Rubem Alves, e sua relevância política1
}

Raimundo César Barreto Junior, Ph.D.2

Rubem Alves foi um dos pensadores mais promissores de sua geração. $\bigcirc$ teólogo Harvey Cox, ao apresentar a obra de Alves aos leitores de língua inglesa, identificou-o como um brilhante pensador, destacando-o dentre uma geração emergente de teólogos do chamado "terceiro mundo"3, que já não podia ser ignorada. Richard Shaull, prefaciando outra obra de Rubem Alves, também usou a expressão "brilhante", referindo-se a ele como uma das mais destacadas vozes que emergiam do "terceiro mundo".4 Como outras mentes brilhantes na história, Rubem Alves é às vezes descrito como um pensador "além do seu tempo", alguém cujo pensamento antecipou tendências importantes. Ele esteve, por exemplo, entre os teólogos latino-americanos que deram à luz a teologia da libertação. Interessante notar que mesmo tendo posteriormente deixado de "fazer teologia", ao menos formalmente, ele tinha grande consciência de seu papel na formação de uma teologia latino-americana. Ao se apresentar numa carta de 2007 ao teólogo escocês lain Torrance, à época Presidente do Seminário Teológico de Princeton, ele assim fez referência ao seu próprio trabalho:

Minha tese de doutorado teve o título Por uma Teologia da Libertação e foi, historicamente, o documento acadêmico que criou a expressão "teologia da libertação". De alguma forma, o Seminário Teológico de Princeton foi o local de nascimento dessa corrente teológica que influencia a vida das igrejas cristãs em todo o mundo..$^{5}$

Embora certos detalhes da sua afirmação quanto à criação da expressão "teologia da libertação" possam ser questionados, Alves, indubitavelmente, estava entre aqueles que deram origem a esse importante movimento do último quarto do século XX. Sua tese foi, de fato, o primeiro livro onde essa expressão foi usada.6 Além do mais, sua contribuição para o

\footnotetext{
1 Palestra proferida na mesa redonda sobre religião e política no dia 29 de agosto de 2019 durante o evento "Repensando o Sagrado: Rubem Alves e a Teologia da Libertação" realizado no Instituto de Ciências Humanas da UFJF.

2 Professor no programa de Cristianismo Mundial e História das Religiões no Seminário Teológico de Princeton, EUA. Contato: raimundo.barreto@ptsem.edu .

3 Como afirma Vijay Prashad, "O terceiro mundo não foi um lugar. Foi um movimento". Um movimento distinto dos dois blocos hegemônicos da Guerra Fria, que a partir da Conferência de Bandung (1955), procurou organizar as vozes, os projetos comuns e a esperança dos povos na África, Ásia e América Latina. Para mais sobre esse tema, ver PRASHAD, Vijay. The Darker Nations: A People's History of the Third World (New York: The New Press, 2007).

4 O prefácio de Harvey Cox se encontra em ALVES, Rubem. A Theology of Human Hope (Washington, DC: Corpus Books, 1969). O prefácio de Richard Shaull pode ser lido em ALVES, Rubem. Protestantism and Repression: A Brazilian Case Study (New York: Orbis Books, 1985).

5 Carta não datada de Rubem Alves a lan R. Torrance, presidente do Seminário Teológico de Princeton no segundo semestre de 2007[tradução do autor].

6 Numa correspondência recente com este autor, Harvey Cox reafirmou que se não fosse pela troca do título de seu livro por parte da editora, Rubem Alves, e não Gustavo Gutierrez, teria recebido o epiteto de "pai da teologia da libertação".
} 
emergente movimento foi distinta. Fazendo referência a uma entrevista de Leonardo Boff por ocasião da morte de Rubem Alves, Paulo Nogueira destaca:

Leonardo Boff, naquela ocasião, em uma nota em um jornal de grande circulação, destacou a diferença da contribuição de Rubem em relação aos demais teólogos da libertação, observando que seu diferencial, além de não adotar o marxismo como mediação teórica, foi se utilizar da psicanálise, e de explorar o universo da subjetividade. $^{7}$

Ao atentar para a subjetividade, Alves incorporaria a literatura e a poesia em sua linguagem teológica, aos poucos abandonando a formalidade da teologia convencional. Transformado em contador de histórias, educador, filósofo, poeta e cronista do cotidiano, seus textos, embora tomando formas diversas, continuaram permeados de temas importantes ao universo teológico.8já no início dos anos 70, ele começaria a desbravar novos caminhos, inclusive no que concerne a um estilo de combinar poesia e teologia que mais adiante formaria o campo da teopoética.

Em correspondência informal, o teólogo Daniel Migliore ressaltou essa habilidade literária do pensador mineiro, afirmando que dada sua capacidade poética e narrativa, Rubem Alves poderia ter escrito romances tão significativos a partir de sua experiência latinoamericana, "que teriam paralelo às tremendas contribuições de alguém como [Toni] Morrison." O professor emérito do Seminário Teológico de Princeton concluiu dizendo: "Se Rubem tivesse escrito um romance desse tipo, tenho certeza de que haveria uma dimensão 'teológica não teológica', assim como há nos romances de Morrison." 9 De certa forma, sua migração da teologia para filosofia e para a poesia-na fase de sua obra que Antônio Vidal Nunes10 identificou como poético-filosófica-gerou uma expectativa de que Rubem Alves caminhava na direção de se tornar um intérprete singular da religião e da alma brasileira.11

O legado do Rubem é, portanto, multifacetado e interdisciplinar. Qualquer tentativa de reduzir seu pensamento a uma ênfase ou sistema distorceria sua obra e violaria a liberdade de uma alma que se mostrou sempre tão inquieta. Sua obra pode ser melhor apreciada a partir dos insights e provocações com as quais nos presenteia; fragmentos que capturam melhor instantes e percepções que ideias sistematizadas. Como um artista que pintava quadros com palavras, Alves encarnou como poucos a alteridade 'intotalizável' do rosto do outro, que ao invés de definições, convida à contemplação e à reverência pelo mistério da vida.12

\footnotetext{
7 NOGUEIRA, Paulo A. S.. "Apresentação do Dossiê: A Poética da Religião em Rubem Alves." Estudos de Religião, v. 31, n. 2: 153-157, maio-agosto, 2017.

8 Dentre os seus criadores, ele também se tornou um dos primeiros críticos do engessamento que notou em outros membros da primeira geração de teólogos da libertação na América Latina. Em seu segundo livro (ALVES, Rubem. Tomorrow's Child: imagination, creativity, and the rebirth of culture (New York: Harper 8 Row, 1972), ele já mostrava estar se movendo para além da teologia da libertação, fazendo uma crítica interna à mesma, ainda em sua fase inicial.

9 Daniel Migliore, em e-mail para o autor, 9 de agosto de 2019.

10 Entre tantos outras, ver seu ensaio "Etapas do Itinerário Reflexivo de Rubem Alves: A Dança da Vida e dos Simbolos." IN: NUNES, A. V. (org.). O Que Eles Pensam de Rubem Alves e de seu Humanismo na Religião, na Educação e na Poesia (São Paulo: Paulus, 2007).

"A pergunta que emerge, em seguida, é: o que impediu que ele atingisse tal patamar? Teria sua notória formação protestante sido um fator que nunca o permitiu alcançar tal nível de penetração nas entranhas culturais da nação?

12 Ver LEVINAS, Emmanuel. Totality and Infinity. Pittsburg: Duquesne University Press, 1998.
} 
A despeito da distinção que acabamos de destacar, não podemos deixar de salientar que, por outro lado, Rubem Alves, assim como nenhum outro ser humano, não pode deixar de ser visto como um homem do seu tempo, como parte de uma geração com limites e influências próprias. No curto espaço desse ensaio, não buscamos uma exposição mais ampla dos diversos movimentos, circunstâncias e indivíduos que influenciaram seu pensamento. Pelo contrário, usando o formato de snapshots, propomos salientar uma influência, em particular, que o marcou profundamente na juventude, e cujo impacto teve consequências para o restante de sua jornada. Nos detemos, portanto, ao impacto do mentor e amigo Richard Shaull sobre a vida e o pensamento de Rubem Alves, atestando a relevância da relação que se formou entre eles. Salientamos características do pensamento teológico de Shaull que podem ser encontradas-na forma de continuidades, expansões, ou descontinuidades-no pensamento do Rubem em diversos momentos de sua vida, e que nos ajudam a fazer sentido do significado social e político do seu pensar.

\section{Sob o Impacto do Encontro com Richard Shaull}

O evento Repensando o Sagrado: Rubem Alves e a Teologia da Libertação, nos dias 27-29 de agosto de 2019, marcou tanto os 50 anos de aniversário da publicação da tese de doutoramento de Rubem Alves nos Estados Unidos, como também o centenário do nascimento do seu mestre e amigo Richard Shaull-que completaria 100 anos no dia 24 de novembro de 2019. Propomos aqui que esses dois personagens estão profundamente interconectados. Sem Richard Shaull, não podemos imaginar se teríamos conhecido o Rubem Alves que viemos a conhecer a partir de meados dos anos 1950. O significado do primeiro na formação do segundo pode ser dimensionado se ouvirmos com atenção as próprias palavras de Alves sobre seu encontro com "Dick Shaull" (como ele era carinhosamente chamado pelos amigos):

O estranho não disse nada. Mas os seus olhos apontaram. E os meus olhos se abriram [...]

[...]E posso dizer que minha vida se divide em dois períodos: antes de conhecê-lo, depois de conhecê-lo [...]

[.... Ele nos ensinou a lição fundamental de teologia: ‘O problema do céu, Deus já o resolveu por nós. Não há nada que tenhamos que fazer. Resolvido o problema do céu, estamos livres para cuidar da terra, que é o nosso destino.' [...]

[...]Se me perguntarem: ‘O que foi que você aprendeu com ele?’ - a resposta é simples: 'Dick Shaull me ensinou a pensar."'13

Em cada uma dessas expressões Alves se refere ao seu encontro com Shaull, em 1953, em tom de tão profunda reverência e gratidão que chega a sugerir uma epifania. $\bigcirc$ conjunto de pequenas descrições desse encontro não deixa dúvidas quanto ao profundo impacto de Shaull na construção do seu pensar.

De fato, a influência de Shaull na formação de toda uma geração de pensadores protestantes brasileiros e latino-americanos nas décadas de 1950 e 1960 tem sido salientada por diversos pesquisadores e ex-alunos..$^{14}$ Essa influência teve tanto cunho teológico como

13 ALVES, Rubem. "su cadáver estaba Ileno de mundo," Religião e Sociedade. Volume 23. Número Especial, 2003, 91-94.

14 FARIA, Eduardo G. Fé e Compromisso: Richard Shaull e a Teologia no Brasil (São Paulo: ASTE, 2002). 
dimensão prática, no contexto das importantes iniciativas de Shaull durante seus anos no Brasil, que contribuíram para a construção de um ecumenismo engajado com a realidade nacional.

Shaull esteve no centro dos principais desenvolvimentos ecumênicos no seio do protestantismo brasileiro e latino-americano naquelas duas décadas. No Brasil, ele e Waldo César criaram o Setor de Responsabilidade Social da Igreja, em 1955, que se tornou um catalizador das mais importantes reflexões e ações ecumênicas da época. ${ }^{15}$ Shaull também teve papel importantíssimo na revitalização da União Cristã de Estudantes do Brasil (UCEB), e na transformação teológica que levou os estudantes daquele movimento a uma profunda imersão nas mobilizações sociais e políticas, num momento efervescente de construção da nacionalidade. De forma direta ou indireta, ele teve influência no surgimento de outras importantes iniciativas ecumênicas no Brasil e afora, como a Conferência do Nordeste (1962), a formação da Junta Latino-Americana de Igreja e Sociedade (ISAL), em 1961, a criação da editora e da revista Paz e Terra (1966), e a formação do Centro Ecumênico de Informação (CEI), em 1965, que mais adiante daria origem ao Centro Ecumênico de Documentação e Informação (CEDI) e à Tempo e Presença.16

Para além de seu ativismo articulador na construção de novos espaços para a ação ecumênica na sociedade, Shaull teve significativo impacto na transformação do pensamento teológico de uma geração que marcaria profundamente o pensamento protestante brasileiro. Jovelino Ramos, um de seus alunos no Seminário Presbiteriano de Campinas, assim descreveu o impacto de Richard Shaull sobre ele e seus colegas:

O Shaull representava um desafio total à nossa maneira de ver as coisas e de reagir ao que víamos... Para ele, aprender não era assimilar conhecimento, mas questionar o conhecimento. "Estou muito mais interessado nas perguntas de vocês do que nas respostas'. 'O que significa o que você acaba de dizer para quem não está acostumado à linguagem dos sermões?' ‘Que tem isso a ver com a situação real dos brasileiros?' (...) $)^{17}$

O teólogo ecumênico uruguaio Julio de Santa Ana fez um relato semelhante:

Shaull era mestre em nos indicar que fazer teologia é tomar parte nas lutas do nosso tempo, participar da história; porque somente nesta e a partir desta é possível encontrar Deus, e sobretudo, criar condições para escutar sua voz (...) Shaull insistia que a prioridade fosse dada à prática. ${ }^{18}$

São inúmeros os testemunhos que demonstram o impacto teológico de Shaull sobre essa geração de pensadores e ativistas protestantes brasileiros. $O$ Rev. Joaquim Beato, de saudosa memória, listou uma série de testemunhos semelhantes, concluindo que Shaull foi "o

\footnotetext{
15 Inicialmente formada como uma Comissão de Igreja e Sociedade independente, meses depois se tornou um setor da Confederação Evangélica Brasileira.

${ }^{16}$ Algumas dessas iniciativas surgiram depois do retorno de Shaull a Princeton. No entanto, como afirmou Waldo César, resultaram do trabalho dele, e contaram com sua colaboração. CÉSAR, Waldo. "Do Individualismo àComunidade:Uma Reflexão sobre os Anos de Richard Shaull no Brasil." IN: De Dentro do Furacão: Richard Shaull e os Primórdios da Teologia da Libertação, organizado por Rubem Alves. São Paulo: Editora Sagarana | CEDI | CLAI, 1985.

17RAMOS, Jovelino. "Você não Conhece o Shaull." IN: ALVES (org.), De Dentro do Furacão, 27.

18 SANTA ANA, Julio. "Richard Shaull: Teólogo e Pioneiro Ecumênico - Um testemunho Reconhecido." IN: De Dentro do Furacão, 37.
} 
teólogo que exerceu a mais profunda influência sobre toda uma geração mais jovem de importantes teólogos brasileiros."19

Rubem Alves fez parte desta geração, vindo a se tornar seu representante mais ilustre. A influência de Shaull sobre ele teve um impacto direto em sua trajetória. Vale lembrar, por exemplo, os esforços de Shaull para levá-lo a Princeton. Em Princeton, Shaull se tornaria o orientador de sua tese de doutorado. Entre o seminário de Campinas e o final do doutorado de Alves em Princeton, em 1968, foram 15 anos de influência direta.

Mais que um mentor, Shaull se tornou um parceiro e aliado. Alves nunca escondeu as dificuldades que enfrentou para a aprovação de sua tese em Princeton. Ele chegou a dizer que houve quem quisesse reprová-lo e que o "passaram por caridade com a nota mais baixa."20Ao mesmo tempo, ele mencionava Shaull como um dos amigos que o apoiaram nos momentos complicados nesse processo que culminou com a publicação da tese que o tornou conhecido na academia. Durante os anos como doutorando em Princeton, Rubem Alves serviu como professor auxiliar (Teaching Assistant) em alguns cursos ensinados por Richard Shaull. Migliore, estudante na época e hoje professor emérito de teologia no Princeton Theological Seminary, afirma que eles formavam uma "dupla dinâmica, compartilhando muito da visão teológica e da experiência de vida, mas também se complementando de maneiras importantes." 21

Portanto, é importante olharmos para a trajetória intelectual de Richard Shaull como uma espécie de prelúdio para a compreensão do pensamento de Rubem Alves. Obviamente, dada a inquietude e criatividade de sua mente, não podemos reduzir Alves - nem sequer uma etapa de sua vida- a uma única influência. Uma profusão de teorias, pensadores e circunstâncias pessoais e históricas podem ser apontadas como formadoras da suajornada intelectual. $\bigcirc$ que destacamos nesse artigo, no entanto,é a singularidade do impacto de Shaull sobre sua formação, considerando, principalmente, o convívio que os dois tiveram na educação teológica que Alves recebeu tanto em Campinas quanto em Princeton.

Vale ressaltar, porém, que a despeito de terem tido uma conexão profunda e duradoura, Shaull e Alves foram pensadores notoriamente diferentes. Migliore distingue os dois da seguinte maneira:

Eu acho que Shaull sempre foi mais um "profeta" e um "guerreiro", e muito menos um "poeta", para usar as categorias de vocação das quais Alves mais tarde falaria. Shaull estava primeiramente comprometido com a ação política e social concreta aqui e agora, para protestar contra a injustiça e a mudança sistêmica em favor de uma maior justiça. Logo no início [como você pode ver em seu [livro] $A$ Theology of Human Hope, baseado em sua tese de doutorado), Alves, embora não discorde dessa orientação política ativista, tem a intenção de ir mais fundo, sondando as fontes da criatividade, imaginação e esperança na vida humana, examinando o uso e o abuso da linguagem, marcando a diferença entre o

\footnotetext{
19 BEATO, Joaquim. "A Conferência do Nordeste 50 Anos Depois." IN: Cristo e o Processo Revolucionário Brasileiro: A Conferência do Nordeste 50 Anos Depois (1962-2012). Org. por Wanderley Pereira da Rosa \& José Adriano Filho (Rio de Janeiro: MAUAD Editora, 2012), 27-38. O itálico é nosso.

20 Para mais sobre esse processo, ver BARRETO, Raimundo. "Rubem Alves and the Kaki Tree: The Trajectory of an Exile Thinker," Perspectivas 13: 47-64 (2016).

${ }^{21}$ Correspondência eletrônica com o autor em 8 de agosto de 2019.
} 
messianismo humanista e o humanismo messiânico, e explorando a importância do corpo, o brincar, o dom da natureza, a experiência da beleza. ${ }^{22}$

Enfim, Alves, embora profundamente impactado por seu encontro com Shaull, ganhou luz própria, desenvolvendo uma forma peculiar de pensar. Na verdade, Shaull - também um pensador assistemático - nunca desenvolveu uma escola de pensamento própria. Ele foi mais um instigador de ideias, representando o que Rubem Alves viria a descrever como "o dedo que apontava para a lua". Por isso, a despeito de suas diferenças, até o final da vida,ele reconheceu o significado do encontro com esse estrangeiro que andava na contramão, convidando homens e mulheres para cavalgar "o vento do furacão".23

Sob esse prisma, voltamos nossa atenção agora para algumas características importantes na teologia de Richard Shaull.

Shaull compreendia a teologia como um processo dinâmico de constante recriação humana em resposta a um Deus que vem a nós do futuro. Tal concepção orientou sua postura sempre aberta para o diálogo com o diferente e para oportunidades de colaboração na construção de futuros alternativos. Alves, de certa forma, levou esta ênfase aos seus limites, contrastando a frustração com uma tradição protestante petrificada pela ideologia com o sonho de um protestantismo criativo, marcado pela imaginação e pelo desejo. Numa entrevista com Elsa Tamez, em 1986, ele evocou a expressão pio conspiratio, usada por Calvino, para propor uma teologia erótica no contexto de uma igreja que ele concebia como uma comunidade de desejos que conspira-respira de forma conjunta. Entre os diversos insights daquela entrevista, ele já deixava claro que essa igreja que ele amava não era uma entidade empírica. Pelo contrário, ele a descreveu como um objeto dos seus sonhos: "Eu sonho com uma igreja, e isso é o que me mantém conectado a ela."24

Em tempos nos quais a esperança dos mais vulneráveis parece ser esmagada diariamente, tanto Richard Shaull quanto Rubem Alves representam um convite à resistência, à subversão, e à construção de sonhos e possibilidades de outros futuros. Nisso, afirmamos, reside a importância política desses dois pensadores. Ambos nos convidam a uma abertura para a transformação e para a constante recriação dos nossos mundos simbólicos, cada um de uma forma peculiar. No caso de Shaull, esse convite se dá num contexto mais teológico e pastoral. No caso do Alves, ele acontece por meio de uma rebelião mais radical que rompe com as amarras tanto da fé institucionalizada quanto da racionalidade enjaulada da modernidade. ${ }^{25}$ Influenciado pela afirmação de Shaull de que o sagrado não podia ser contido

\footnotetext{
22 Ibid [tradução do autor]. Aqui ele se refere aos tipos profeta, guerreiro e poeta que Rubem Alves apresenta no livro The Poet, the Prophet, and the Warrior (London: SCM Press ; Philadelphia : Trinity Press International, 1990).

23 Expressões que Alves usou para falar sobre Richard Shaull. Ver ALVES, Rubem. "O Deus do Furacão." In: ALVES, Rubem (org.). De Dentro do Furacão: Richard Shaull e os Primórdios da Teologia da Libertação(São Paulo: CEDI/CLAI, 1985), 19-24.

24 TAMEZ, Elsa. Against Machismo: Rubem Alves, Leonardo Boff, Gustavo Gutiérrez, José Miguez Bonino, Juan Luis Segundo... and Others Talk about the Struggle of Women: Interviews (Oak Park, III: Meyer-Stone Books, 1987), 68-75.

${ }^{25}$ Ao salientarmos esse protesto de Rubem Alves contra o aprisionamento da razão moderna, identificamos uma outra área que desbravou sem nomear. Estaria Alves, ao seu próprio modo, avançando uma forma de decolonidade?
} 
nos jardins internos da religião, Alves se tornaria um exemplo vivo do que pode acontecer quando o sagrado se derrama e se perde na amplitude da existência. ${ }^{26}$

\section{O Resgate do Legado Profético da Reforma Protestante}

Richard Shaull teve um papel fundamental no desenvolvimento da teologia latinoamericana, como um intelectual orgânico que fomentou uma nova linguagem teológica, dando início aum incipiente diálogo entre o protestantismo e a realidade sociocultural latinoamericana. Shaull expandiu os horizontes do cristianismo brasileiro, contribuindo para o surgimento de uma teologia que passaria a tomar a realidade cultural, social e política latinoamericana como seu locus de enunciação. Como Rubem afirmou, nesse processo, sem saber, Shaull estava lançando as sementes da teologia da libertação. 27

Durante seis décadas, sua relação com a América Latina tomou várias formas. 28 Inspirado por John Mackay, DickShaull seguiu para a Colômbia, em 1941, onde serviu como missionário. Nesse primeiro momento, ele buscou desenvolver uma teologia pastoralmissiológica para interpretar uma realidade profundamente afetada pela pobreza, violência e sofrimento. O segundo momento acontece no Brasil, a partir de 1953, quando ele cumpriu o papel de um teólogo orgânico num emergente movimento ecumênico que buscava amadureceruma nova forma de pensar. Um novo modo dessa relação se dá quando, de volta a Princeton, em 1962, Shaull se tornaria um "evangelista", isto é., intérprete e difusor do emergente pensamento teológico latino-americano no contexto dos EUA, propondo a partir deste lugar um diálogo mais substancial entre a teologia reformada norte-americana e a emergente teologia latino-americana da libertação. ${ }^{29}$

Principalmente nessa fase, nota-se seu interesse crescente na renovação da tradição reformada, que ele considerava estar à beira de uma mórbida estagnação. Para ele, uma tradição que tendia a repetir respostas passadas ao enfrentar novas situações e desafios num mundo em constante transformação corria o risco de esclerose.30 Por outro lado, ele enxergava um potencial de renovação naquela tradição, principalmente na sua afirmação de um Deus transcendente, mas que, ao mesmo tempo, "permanece ativo na história."31

\footnotetext{
26 Migliore levanta as seguintes questões: "Será que ele conseguiu (ou mesmo quis) se desfazer de todos os compromissos teológicos profundos? Teria ele negado o discurso de Barth sobre Deus como "totalmente outro"? Teria ele renunciado à ideia de que as histórias e imagens da Bíblia que falam de uma nova vida,de esperança e beleza como presentes que não fabricamos, mas que só podemos receber, são tesouros preciosos? Será que ele concordou com Bonhoeffer que o nosso é um tempo em que é necessário falar "não religiosamente" de Deus? Será que ele desistiu daquele grande refrão da igreja reformada: a igreja reformada (incluindo sua teologia) sempre se reformando?" Todas essas indagações podem ser aprofundadas no desenvolvimento da futura agenda da Sociedade Internacional Rubem Alves, criada nesse encontro. Correspondência eletrônica com o autor, 8 de agosto de 2019[tradução do autor].

27 Essa impressão foi reiterada por muitas outras pessoas. Migliore lembra que em seu último ano como estudante do mestrado no Seminário de Princeton, em 1959, ele se matriculou num curso ensinado por Shaull, que se encontrava num sabático do seu trabalho na América Latina. Ressaltando o quanto os cursos de Shaull eram eletrizantes, ele afirmou que seus estudantes, sem o saber, estavam ouvindo "sobre os desenvolvimentos eclesiais na América Latina que acabariam se tornando a matriz da teologia da libertação latino-americana." Correspondência eletrônica com o autor, em 8 de agosto de 2019.

${ }^{28}$ No final de sua vida, Shaull se referiu a essas fases como conversões. BARRETO, Raimundo. "A 'Terceira Conversão' de Richard Shaull, Religião e Sociedade, Volume 23. Número Especial, 2003, 83-90.

29 SHAULL, Richard. The Reformation and Liberation Theology: Insights for the Challenges of Today (Louisville, KY: Westminster/John Knox Press, 1991).

30 Ibid., 15.

31 Ibid., 15-16.
} 
Para Shaull, a presença ativado Espírito de Deus no mundo é um fato eminentemente inovador. Essa atenção ao agir do Espírito no mundo o levou a uma profunda interação com o movimento pentecostal, que marcou a última fase de sua vida. Movido por uma compreensão aguçada do privilégio hermenêutico dos menos favorecidos, Shaull voltou sua atenção, em particular, para o mundo simbólico dos pobres que, em sua percepção, era permeado pela linguagem pentecostal.

Por toda a sua vida, Shaull insistiu em reinterpretar o legado da Reforma Protestante a partir de novos locais de fala, e em diálogo com outras tradições. Isso o levou a acessar novas lentes para a releitura e a inovação de um legado teológico que, para ele, precisava escapar da estagnação. Essa abertura fundamental para o novo o permitiu interpretar a ação redentora de Deus na história como um processo libertador. No drama da ação libertadora de Deus no mundo, pessoas e comunidades vitimadas pela violência e injustiça recuperam a agência perdida no processo de construção de seu futuro.32 Sendo assim, a fé num Deus transcendente, mas presente na história por meio das irrupções transformadoras do divino, cria condições para a transformação das condições de existência.

Embora a formação de seu pensamento tenha antecedido seu contato com a América Latina, Shaull ressaltou inúmeras vezes que sua reflexão teológica aprofundou-se significativamente no encontro com a realidade latino-americana, e, acima de tudo, no convívio com um grupo de ávidos estudantes protestantes brasileiros em princípio dos anos 50 . Foi em diálogo com aqueles estudantes que ele passou a investigar mais profundamente a conexão entre o legado reformado e a transformação social, iniciando um processo de reexame crítico da história e da teologia protestante à luz da nova realidade que encontrara no contexto latino-americano. ${ }^{33}$

\section{Influências Teológicas em Richard Shaull}

Desde cedo em sua caminhada, Shaull demonstrou interesse na compreensão teológica do 'drama humano'. Mas foi seu encontro com o teólogo Emil Brunner, ainda como seminarista em Princeton, que o ajudou a enxergar a realidade como parte de um drama de dimensões cósmicas, que Brunner chamou de encontro divino-humano, o qual punha a presença ativa e compassiva de Deus no centro da existência humana. Sendo assim, não era mais possível falar de Deus sem se referir ao humano, nem tampouco se compreender a

\footnotetext{
32 SHAULL, Richard Shaull. "A Theological Perspective on Human Liberation," New Blackfriars, 49/578 (1968): 509-517 (511).

33 SHAULL, Richard. "Toward the Recovery of the Prophetic Power of the Reformed Heritage." IN: The Future of Prophetic Christianity: Essays in Honor of Robert McAfee Brown. Edited by Denise L. Carmody \& John T. Carmody (Maryknoll, NY: Orbis Books, 1993), 59-66 (59). Vale lembrar, que, em contraste com o que testemunharam muitos de seus alunos, os quais sempre Ihe atribuíram grande crédito na formação deste movimento, Shaull, em si, nunca se viu como iniciador de um movimento. Pelo contrário, para ele a situação brasileira na ocasião de sua chegada ao Brasil já estava madura para o que ele viria a oferecer, e a ele coube apenas o papel de catalizador. Em suas próprias palavras: "Antes da minha chegada ao Brasil, um novo espírito já invadia a Igreja. Vários homens e mulheres já estavam em contato com a evolução da teologia na Europa e nos Estados Unidos, e tinham sua própria visão sobre a renovação da Igreja. Quase todas as minhas iniciativas foram precedidas de esforços iguais por parte de outras pessoas, que, desenvolvidos por outros grupos, ultrapassaram o que fiz. De minha parte, apenas contribuí com algo muito pessoal para aquela situação. Tornei-me ao mesmo tempo um agente catalisador. Talvez isso tenha sido inevitável. Tenho a impressão agora de que esse fator talvez tenha impedido outras pessoas de tomarem suas próprias iniciativas." SHAULL, Richard. "Entre Jesus e Marx: Reflexões Sobre os Anos que Passei no Brasil." In: ALVES, Rubem (org.). De Dentro do Furacão," 189.
} 
existência humana à parte da graça e da ação divina. Para Shaull, portanto, "nossas vidas se desenrolam no contexto do drama cósmico da redenção, nos caminhos da restauração da vida humana e da transformação do mundo".34 Essa convicção conformaria as questões que veio a levantar sobre o significado da responsabilidade e do compromisso cristão para com a transformação de realidades injustas.

A fé em Jesus Cristo ocupou um lugar central no pensamento de Shaull, do começo ao fim de sua vida. Entre os intelectuais com quem interagiu desde a juventude, vários se esforçavam para renovar o sentido da fé cristã num "mundo tornado adulto", no qual a hipótese de trabalho 'Deus' já não parecia necessária.35Ao invés de se sentir aprisionado pela fé cristã, Shaull entendia que ela o libertava para ousar e dialogar com inúmeras outras formas de pensar, já que, para ele, Deus estava agindo constantemente no mundo, muito além da esfera da igreja. Os cristãos eram, portanto, instigados a discernirem a ação divina através da imersão radical no mundo, e a responderem a ela de forma moralmente responsável e livre.

O teólogo tcheco Josef Hromadka, convidado por John Mackay para ensinar por um tempo em Princeton, também se tornou um importante mentor teológico de Shaull. Entre outras coisas, ele chamou sua atenção para "os sinais da crise emergente da civilização ocidental" e para a "necessidade de entender o marxismo e seu papel no mundo revolucionário." Na caminhada posterior de Shaull na América Latina, a categoria 'revolução' viria a ocupar espaço importante na sua reflexão. Além disso, a influência de Hromadka contribuiu também para que ele adotasse uma perspectiva escatológica que marcaria tão profundamente sua forma de pensar e enxergar o mundo que alguns passariam a se referir a Shaull como "o profeta do futuro".36 Enfatizando a centralidade da escatologia nas Escrituras, Hromadka o convenceu do valor de compreender a realidade a partir de suas possibilidades futuras. De acordo com essa perspectiva:

Podemos entender melhor nossa luta pela vida no confronto com o que virá a ser. Podemos agir mais responsavelmente no mundo quando guiados pela visão daquilo que mais contribui para sua futura transformação.

Esse olhar persistente para os acontecimentos no mundo a partir da perspectiva "do que pode vir a ser" fez de Shaull um profeta de um novo tempo, alguém capaz de interpretar os acontecimentos históricos com os olhos não apenas no presente, mas também na transformação futura à luz do Reino de Deus.

Rubem Alves descreve essa característica profética do seu antigo mentor com a distinção poética que marcou seus escritos:

Profetas não são videntes que anunciam um futuro que vai acontecer. Profetas são poetas que desenham um futuro que pode acontecer. Profetas sugerem um

\footnotetext{
34 Quando outra fonte não for indicada, esses relatos se baseiam em sua autobiografia, SHAULL, Richard. Surpreendido Pela Graça: Memórias de um Teólogo -Estados Unidos, América Latina, Brasil (Rio de Janeiro: Record, 2003).

35 Essa expressão faz uma referência óbvia a Dietrich Bonhoeffer, um dos teólogos influentes na formação do pensamento teológico de Shaull. Ver referência ao mundo tornado adulto, por exemplo, BONHOEFFER, Dietrich. Resistência e submissão: cartas e anotações escritas na prisão (São Leopoldo: Sinodal, 2003), 434.

36LEÃO NETO, Reynaldo F. Richard Shaull: O Profeta da Revolução. Pastoral e Mística. Cadernos de PósGraduação/Ciências da Religião, 13/8 (1995): 83-110 (105).
} 
caminho. Richard Shaull falava de futuros com os quais nós nunca havíamos sonhado. Ele via o que ninguém mais estava vendo.37

$\mathrm{Na}$ linguagem de Alves, o profeta e o poeta se confundem no papel de sugerir possíveis futuros.

O próprio John Mackay, presidente do Seminário de Princeton na época, e exmissionário na América Latina, foi outra influência significante na formação de Shaull. A teologia de Mackay afirmava uma compreensão da natureza da fé cristã que conduzia inescapavelmente à ação. Em suas memórias, Shaull recorda que, em contraste com a rigidez doutrinária característica de muitos protestantes reformados, Mackay gostava de relembrar seus alunos que a verdade é para a bondade". Uma das analogias mais conhecidas de Mackay é a imagem da varanda e da rua. Para ele, os cristãos não são chamados para permanecer na varanda, como meros observadores dos acontecimentos históricos, mas para descer às ruas, assumindo "um comprometimento apaixonado para com o sofrimento do povo nas suas lutas concretas." Essa imagem certamente impactou a formação de Shaull e da sua teologia voltada para a práxis.

Dentre as inúmeras influências na formação teológica de Shaull, há duas outras que não podemos deixar de mencionar. Quando voltou da Colômbia para os Estados Unidos, Shaull estudou, em momentos diferentes, com Reinhold Niebuhr e com Paul Lehmann. Embora não se deva ignorar o impacto de seus estudos com Niebuhr - principalmente no que concerne o tema do 'comunismo', que influenciou sua análise teológica da revolução38 - foram seu convívio e estudos com Lehmann que mais contribuíram para algumas das características que marcaram mais profundamente seu pensamento teológico.

Quando Dietrich Bonhoeffer passou um ano estudando no Union Theological Seminary, no ano acadêmico de 1930-1931, Lehmann se tornou um de seus amigos mais próximos. Desde então, eles se mantiveram em contato até a morte trágica do brilhante pensador alemão. Lehmann, de certa forma, acabou incorporando algumas das ênfases de Bonhoeffer em sua própria teologia. Shaull, influenciado pelos estudos com Lehmann, refletiu em sua forma de teologizar tanto um quanto o outro. Ele se tornou um intérprete do pensamento destes dois teólogos para seus estudantes brasileiros na década de 1950. Enquanto Bonhoeffer contribuiu para a radicalização de sua compreensão da comunidade cristã e de seu papel no mundo, concebendo a igreja de forma mais orgânica-como a comunidade onde Cristo está sendo formado-, Lehmann ajudou Shaull a entender que "a ética cristã é orientada

\footnotetext{
37 ALVES (2003) op. cit., 92 No prefácio da versão em inglês do livro Protestantismo e Repressão, Shaull afirma que chegou a questionar a relevância do argumento de Alves. Sua razão foi: "Alves não tem intenção de nos apresentar um modelo da forma das coisas que estão por vir neste país." Aos poucos, entretanto, sua resistência foi vencida. Ele compreendeu melhor o significado daquela contribuição quando passou a ler a análise crítica das instituições religiosas brasileiras oferecida por Alves como um insight para expandir sua própria visão crítica das instituições religiosas nos EUA. Isso Ihe deu "um senso mais claro do que precisa ser feito aqui," Ihe encorajando "a tomar novas iniciativas." Esse é um exemplo explícito da orientação dominante de Shaull para a práxis transformadora a partir de uma perspectiva escatológica. ALVES (1985), op. cit.

38 Ver alguns textos sobre esse tema no livro SHAULL, Richard. Encounter with Revolution (New York: Association Press, 1955). Apesar de frequentemente acusado de comunista pelos seus detratores, Shaull, influenciado pelo legado reformado de pensadores como Niebuhr, se via num campo diferente, crítico da alternativa marxista (assim como da capitalista), embora vendo nela elementos que podiam inspirar os cristãos.
} 
antes para a revelação que para a moralidade". ${ }^{99} \mathrm{Em}$ outras palavras, o mandato cristão começa não com um axioma moral, mas com um interesse no que se passa ao nosso redor, com o propósito de discernir as ações humanizadoras de Deus no mundo. 40 Ao invés de serem portadores de respostas prontas, teólogos e eticistas cristãos são desafiados a serem aprendizes, abertos para discernir o que Deus está fazendo de novo no mundo. Essa atitude de permanente abertura para aprender $\mathrm{O}$ novo permitia o contínuo reajuste das agendas teológicas. Não há, assim, qualquer agenda teológica que se possa conceber como definitiva. A teologia é uma práxis sempre em aberto, realizada em humildade, por indivíduos e comunidades que aprendem através de sua imersão no mundo.

Foi essa atitude que tornou Shaull um corpo, nas palavras de Rubem Alves "lleno de mundo", e que informou sua agenda e suas parcerias para o diálogo. Num determinado momento, a revolução se tornou o tema mais urgente de seu interesse intelectual, e ele buscou compreendê-la teologicamente em diálogo com marxistas e outros teóricos e ativistas. Num momento mais adiante, ele se interessaria pelo tema da libertação, e a partir de então se tornaria aprendiz de seus ex-alunos e das Comunidades Eclesiais de Base - CEBs. Mais ao final de sua vida, a partir do final da década de 80, essa abertura para o constante agir de Deus no mundo o levaria à imersão emcomunidades pentecostais, como as comunidades economicamente empobrecidas no Rio de Janeiro que pesquisou em meados dos anos $90 \mathrm{com}$ Waldo César,a partir de onde ele queria entender teologicamente a mudança no discurso evangélico da sua ênfase tradicional na salvação para uma ênfase na solução. ${ }^{41}$

A grande virtude de Shaull, como já salientamos, residiu em sua habilidade de combinar diferentes insights teológicos e aplicá-los de forma arguta na interpretação da realidade vigente. Seu olhar estava sempre voltado para a prática e para a transformação do mundo. A partir da realidade onde se inseria, e sempre em diálogo com outras tradições, ${ }^{42}$ ele, repetidamente, reinterpretou e reinventou o legado profético do protestantismo reformado. Isso marcou também a formação de seus pupilos.

\section{A Influência Protestante de Shaull sobre Rubem Alves}

Como mostramos mais cedo, Rubem Alves resumiu o impacto de Richard Shaull sobre seu pensamento com a frase "Dick Shaull me ensinou a pensar."

\footnotetext{
39LEHMANN, Paul. Ethics in a Christian Context (Eugene: Wipf and Stock Publishers, 1998), 54 [tradução do autor].

40 Para Lehmann, a primeira pergunta ética não era "o que eu devo fazer?", mas "o que Deus está fazendo no mundo?"De acordo com ele, Deus está sempre agindo para tornar a vida humana mais humana. A ação de Deus no mundo é, portanto, sempre uma ação humanizadora. A comunidade ou koinonia cristã é chamada a discernir os atos humanizadores de Deus no mundo, e a se juntar a Deus nesse agir, em conjunto com membros de outras comunidades onde "Cristo está sendo formado".

4ISHAULL, R. \& CESAR, W. Pentecostalism and the Future of the Christian Churches. Grand Rapids: W.B. Eerdmans Publishing Co., 2000.

42 O diálogo foi o modus operandi de Shaull. Ele estava sempre em diálogo com cristãos de diferentes tradições e com pensadores e ativistas não cristãos. Exemplos desse estilo dialógico de atuar podem ser vistos, acima de tudo, em trabalhos escritos em parceria com católicos ou com ativistas seculares, como no caso do livro Liberation and Change (Atlanta, GA: John Knox Press, 1977), um diálogo teológico com Gustavo Gutierrez, e do livro Containment and Change (New York: Macmillan, 1967), co-escrito com Carl Oglesby, um ativista político que presidiu o movimento de esquerda Students for a Democratic Society.
} 
Shaull foi o mentor que mais participou da formação de Alves, desde o seu início, no Seminário Presbiteriano, em Campinas, até o final do seu doutorado, em Princeton. Como tal, ele esteve presente na primeira importante guinada intelectual de Rubem Alves, quando este abandonou sua formação religiosa inicial, à qual se referiu em alguns momentos como fundamentalista, e começou a desenvolver um pensamento mais crítico, em contato com a filosofia e a ciência. Na fase em que Rubem começou a formular sua própria teologia, Shaull teve papel central - como professor e orientador - na construção das bibliografias a serem lidas e de temas e questões a serem problematizados. Essa influência pode ser notada até mesmo nas escolhas temáticas de seus primeiros escritos, inclusive em sua tese de doutorado.

Em artigo publicado pelo The Ecumenical Review, em 1970, Alves refletiu sobre a função ideológica do protestantismo latino-americano e suas possibilidades utópicas. Neste ensaio, ele elabora seu raciocínio a partir de um contraste entre ideologia e utopia, um tema que reapareceria com roupagens variadas em outros de seus escritos. Ele define ideologia como uma estrutura mental voltada para a preservação das coisas como são, ao passo que descreve utopia como algo que "promove e direciona ações que levam a mudanças." 43 Ao tratar das possibilidades utópicas do protestantismo, Rubem elogia sua ênfase na liberdade do "homem"[sic]em Lutero, destacando também o Princípio Protestante articulado por Tillich, que enfatiza a "rejeição radical" protestante "do caráter final ou sagrado de todas as estruturas." 44

Embora afirme essa ênfase protestante na liberdade individual, ele, por outro lado, critica o dualismo que percebe, especificamente, no protestantismo latino-americano, no qual a dimensão estrutural da injustiça foi perdida em favor de uma ênfase exacerbada na fórmula da transformação do indivíduo. A fim de resgatar o caráter político da ética protestante, Alves propõe uma dialética que seja capaz de produzir uma ética da mudança que percebe a transformação do mundo como vocação. Comparando as duas perspectivas, Alves ressalta que enquanto o protestantismo como ideologia "apoia as forças que desejam perpetuar as estruturas dominantes," o "protestantismo como utopia [...] está aberto ao futuro e exige uma ética de mudança social". Considerando o antagonismo dessas propostas insuperável, ele aponta para uma nova forma de ecumenismo que vem emergindo entre protestantes 'utópicos' e católicos com uma orientação "messiânico-profética".45

Neste texto, embora encontremos características próprias do seu próprio pensamento e referências a pensadores como Dewey, Wittigenstein, Mannheim, Freud, Buber e Nietzsche, a proximidade do pensamento de Shaull permanece visível, mesmo que este não seja citado diretamente.

Três anos mais tarde, em 1973, a revista Christianity and Crisis, fundada por Reinhold Niebuhr em 1941, convidou Rubem Alves para responder a um artigo de Thomas G. Sanders, um dos pupilos de Niebuhr, que acusava a teologia da libertação latino-americana de ser meramente um tipo de "utopismo suave"46. Alves, numa resposta que mostrava grande indignação—não tanto por aquilo que Sanders escreveu, mas pela forma que o fez-expôs

\footnotetext{
43 ALVES, Rubem. "Protestantism in Latin America: Its Ideological Functions and Utopian Possibilities." The Ecumenical Review 22/1 (1970): 1-15 (4).

44 Ibid., 7.

45 Ibid., 14.

${ }^{46}$ A expressão utopismo aqui, na boca de um realista, sendo usada de forma perniciosa.
} 
com brilhantismo os problemas não apenas do argumento de Sanders, em si, mas também do realismo cristão como um todo, a que chamou de "ideologia do establishment".47

Alves apontou, principalmente, para o autoengano dos cristãos realistas por não compreenderem que o que chamam de realidade nada mais é que uma construção humana. Ao acusarem os teólogos da libertação de um utopismo que os torna propensos à ilusão, eles deixavam de perceber a natureza ilusória do seu próprio conceito de realidade. Movidos por uma arrogância imperialista, teólogos como Sanders aplicavam critérios para avaliar a emergente teologia latino-americana que não usavam para examinar sua própria forma ideológica de teologizar. Por outro lado, a negatividade que davam ao termo utopia terminava resultando no que Alves chamou de eclipse da imaginação. No argumento desse artigo de 1973, assim como no anterior, o binário ideologia $x$ utopia prepondera. Apesar de não mencionar Shaull ou Lehmann, a estrutura do argumento permanece fortemente influenciada pelos dois. O termo "ideologia do establishment", por exemplo, que ele usa já no título do artigo para se referir ao realismo cristão, tem nítida inspiração na expressão "lógica do establishment", usada por Lehmann, que também criticava o establishment por não criar lugar para o novo. ${ }^{48}$

Treze anos mais tarde, em 1986, por ocasião da celebração dos 450 anos de Calvino, em Genebra, Rubem voltaria a falar de sua relação com o protestantismo em termos que ainda refletiriam o binômio utopia-realidade, mesmo que usando novas expressões:

\begin{abstract}
O Protestantismo faz parte do meu corpo, meu sonho, meu pesadelo, algo que eu amo, algo que eu odeio ... Sim, eu estava sonhando, estou sonhando, você é meu sonho, Genebra, todas as fantasias que posso colocar nesses 450 anos.

O que tenho a oferecer não são ideias claras e distintas, mas sonhos: convido você a ver o protestantismo a partir de um ponto de vista não-protestante: desfrutar do protestantismo a partir de uma bolha não-protestante ... E devo lhe contar um segredo: houve um momento em que eu estava prestes a vomitar o protestantismo - era necessário, para mim, sair dele e prová-lo como um sacramento em uma terra diferente ... E de uma coisa ruim ele se tornou um sonho: e o que era amargo tornou-se doce. ${ }^{49}$
\end{abstract}

Nesse momento, em 1986, Rubem já havia feito a transição da teologia para a teopoética. Embora nessa fase de seu pensar, Alves já não fale necessariamente em utopia, ele continua rejeitando uma ideia fixa de 'realidade' (baseada na sua compreensão de ideologia), movendo-se para além da racionalidade inibidora do novo, de forma ainda mais radicalmente aberta para a imaginação, a fantasia e o sonho (termo que vai substituir utopia nessa fase). A estrutura messiânico-profética, presente, como já vimos, no pensamento de Shaull, influenciou o jovem Alves, como podemos notar na seguinte passagem:

E nos esquecemos que é em nossos sonhos e desejos que reside, escondida, a possibilidade de salvação. $\dot{E}$ uma promessa messiânica: que aqueles que não têm futuro, os idosos, sonharão ... Nossos desejos podem ser belos: fragmentos da imagem de Deus. E nada tem o poder de mover o corpo como a beleza.

\footnotetext{
47 ALVES, Rubem. "Christian Realism: Ideology of the Establishment." Christianity and Crisis 33 (1973): 173176. Vale a pena destacar que o realismo cristão de Niebuhr foi uma das mais influentes ideologias do establishment norte-americano no pós-guerra.

48 LEHMANN, Paul. The Transfiguration of Politics, by PAUL LEHMANN. Harper \& Row, Publishers, New York, 1975. Alves escreveria posteriormente uma resenha bastante favorável deste livro.

49 ALVES, Rubem. "An Invitation to Dream." In: The Ecumenical Review. World Council of Churches. Vol.39 - No 1- January. p. 59-62 (60): 1987 [tradução do autor].
} 
Profundamente, dentro de nossa carne, um gemido é ouvido, e suas reverberações são sentidas por toda a criação, suspiros que são profundos demais para palavras, desejos sem nome. Mas não importa: um Vento os ouve e compreende nossos suspiros sem palavras e os leva a Deus: nossa oração. Todo sonho é uma oração. 50

Nessa passagem repleta de beleza poética, reencontramos a ideia messiânica de salvação, agora tendo os sonhos, o corpo e a beleza como suas mediações. Imagens como o vento, o ar e a música passam a aparecer de forma mais constante.51 $O$ silêncio é reverenciado, pois evoca uma ausência. Como poeta, Alves já não fala palavras para serem meramente compreendidas pela razão. Pelo contrário, ele quer que elas sejam saboreadas, digeridas pelo corpo. De poeta, Rubem Alves se torna um cozinheiro, cujo "fogão é o seu próprio corpo, aceso pela imaginação."52

A esta altura, sua voz crítica fala a partir de fora das instituições protestantes. Seus novos mestres não se encontram nas igrejas: "Eles adoram altares solitários: poetas, pintores, mágicos, antropólogos, personagens medievais e bizarros do mundo dos contos de fadas e ... crianças."53 A palavra que Alves traz para os protestantes vem de "diferentes tradições e religiões que nos olham com espanto" pois notam "que nos falta a poesia, que não amamos o mistério das florestas e a profundidade do mar, que nos escondemos da escuridão do nosso lado noturno e guardamos em segredo os sonhos que sonhamos à noite."54

Ainda assim, ele reconhece que o que fala não passa de "uma 'variação' de um motivo que foi proposto e desenvolvido primeiro em seu quintal". Sua formação protestante, portanto, não desaparece. Ela se transforma em sonho, símbolo e imaginação.

O protestantismo é, para mim, um sonho. Eu o amo porque, quando sou possuído por seus símbolos, sinto que meu corpo se torna mais leve, quase voa. Eu amo o medo calvinista de todos os tipos de idolatria [...] Sim, eu amo o medo calvinista de todos os tipos de idolatria: porque então nós temos que marchar adiante com as mãos vazias. $\mathrm{E}$ nossos olhos se tornam mais suaves... 55

Por fim, ele afirma amar "a beleza da solidão profética":

Eu amo a beleza da solidão profética, quando você está totalmente sozinho, e você é deixado com sua última palavra, a palavra que você sente que tem que dizer para poder morrer, e mesmo se o mundo inteiro dissesse que deveríamos manter silêncio, você ainda a diria, a partir da paixão infinita que queima em altares dentro do seu corpo. Quão bela é essa solidão profética: como Vênus, sozinho, no céu azul após o pôr do sol ...56

\footnotetext{
50 ALVES, "An Invitation to Dream," op. cit.[tradução do autor].

51 Deus é descrito em termos de nostalgia. De acordo com Alves, "O que nos referimos com o nome de Deus é assim: um grande e enorme Vazio que abrange toda a beleza do universo." ALVES, Rubem. Transparencies of Eternity (Kindle Location 167).

52 ALVES, Rubem. "Theopoetics: Longing and Liberation" IN: Struggles for Solidarity: Liberation Theologies in Tension. Edited by Lorine M. Getz and Ruy O. Costa (Minneapolis, MN: Fortress Press, 1992), 160.

53 ALVES, "An Invitation to Dream," op. cit.

54 Ibid.[tradução do autor]

55 Ibid., 61.[tradução do autor]

56 Ibid., 62.[tradução do autor]
} 
Aqui, o poeta e o profeta se beijam. Rubem fazia a escolha pela poesia, em contraste com o ativismo profético-político de Shaull. Ainda assim, permanecia apreciando a tradição profética que a esta altura retratava como um símbolo, uma visão, uma nostalgia.

\section{Em Lugar de uma Conclusão: a relevância política de Rubem Alves}

Em 1993, Rubem aceitou um convite para falar na Conferência da Associação Presbiteriana de Saúde, Educação e Bem-Estar, em Albuquerque, nos EUA.57

Após falar sobre sua transição de teólogo da libertação para poeta, ele criticou as igrejas por se permitirem guiar por uma pedagogia cartesiana, baseada em "ideias claras e distintas".

Em sua fala, Rubem lembrou a classificação de Santo Agostinho, um de seus teólogos prediletos, que divide a vida em duas classes de coisas: aquelas a serem usadas, que pertencem à ordem da utilidade, e coisas que pertencem à ordem da fruição. Para Alves, as coisas que nos fazem felizes não são as da primeira categoria, mas as da segunda. "Felicidade tem a ver com coisas que são totalmente inúteis," ele afirmou;58 e um dos grandes problemas da igreja é justamente ter esquecido disso. Para o Rubem Alves, "os seres humanos são movidos pela beleza." Portanto, "se queremos mudar o mundo, precisamos antes de mais nada levar as pessoas a sonharem com a beleza." 59

Essa sobreposição entre o desejo de mudar o mundo e a beleza merece atenção. Aqui parece estar a chave para lidar com o aparente dualismo entre o teólogo da libertação e o poeta que encontramos em Alves. Essa sobreposição nos captura particularmente para a possibilidade de uma combinação dos tipos "poeta" e "profeta". Na medida em que avançou em sua trajetória, Alves pareceu ter feito uma escolha clara pelo caminho da poesia e da beleza, em detrimento daquele do profeta, no estilo de Richard Shaull. Embora a opção por um não necessariamente anule o outro, no caso de Alves, ele certamente se moveu da ética para a estética, da ênfase no fazer para uma no contemplar e no sonhar. Essa foi sua proposta para os presbiterianos norte-americanos que encontrou em Albuquerque, em 1993. Haveria ele, então, abdicado totalmente da necessidade da ação na polis? Ao menos nesse texto do início dos anos 1990, esse não parecia ser o caso. Em determinado momento, ele pergunta retoricamente: "Qual é o significado disso para a política?" E eis sua resposta:

Parece-me que existe uma política que emerge de uma azia. Quando você tem algo queimando dentro de você, essa chama se torna uma ação política. E a ação política se torna amarga, porque não se baseia em uma visão de beleza. Mas há outro tipo de ação política semelhante à de Michelangelo e da Pietà...60

Essa passagem pode ser vista como uma admissão de que existe lugar para a ação política no pensamento de Alves, mas esta não pode ser compreendida em sua forma mais tradicional. Em uma realidade marcada por divisões, sofrimento, tragédia, horror, destruição e morte, Rubem Alves propõe "que comecemos a operar com a estética da beleza." Mover as pessoas a partir da beleza.

\footnotetext{
57 ALVES, Rubem. "From Liberation Theologian to Poet: A Plea that the Church Move from Ethics to Aesthetics, from Doing to Beauty," Church \& Society, May-June 1993: 20-24 (20).

58 Ibid., 23.

59 Ibid. [tradução do autor].

60 Ibid [tradução do autor].
} 
Paraíso, brincar, alegria, prazer. Se formos capazes de operar com esse tipo de visão, poderemos despertar nas pessoas os sonhos que estão adormecidos dentro delas. E eles serão ressuscitados. 61

Nos parece que de uma forma dialética, a ética e a estética se encontram nessa proposta, a beleza e o desejo de transformar a realidade, não a partir de seu exterior, mas a partir dos corpos e corações, a quem somente a beleza pode mover. Sendo assim, não devemos simplesmente descartar o Rubem Alves mais maduro quando nos voltamos para o âmbito da ação - da ética e da política. Embora encontremos recursos mais claros para um discurso voltado para a justiça nos escritos do jovem Rubem Alves, talvez seja possível, e até mesmo promissor, usar o método dialético que ele próprio usou para avaliar o protestantismo como ideologia e como utopia.

Quando observamos a obra de Alves, identificamos os persistentes resquícios do que alguém chamou de um "programa de utopismo radical" como um possível viés de encontro entre a ética e a estética em seu pensar.62 No prefácio do livro The Poet, the Warrior, The Prophet, Jo Ind expressa sua dificuldade de categorizar a obra de Alves. Seria ela teologia, poesia, psicoterapia, literatura ou teoria linguística? No final das contas, Ind desistiu de tentar uma classificação, confiando que Rubem sabia o que estava fazendo quando não compartilhou uma classificação com seus leitores.

Nesse artigo, focalizamos pequenos flashes da vasta obra de Alves, observando que as imagens do poeta e do profeta que a permeiam não se excluem mutuamente. Essa talvez seja uma pista para revisitarmos suas contribuições no confronto com ideologias paralisantes que continuam produzindo conceitos aprisionadores de verdade, certo e errado, e bem e mal, aprofundando divisões, preconceitos e o sofrimento. Tais ideologias continuam legitimando a opressão, a violência, o racismo, o genocídio étnico-cultural, a misoginia, a homofobia, o preconceito religioso, o preconceito contra os pobres e a destruição de nossa grande casa, o planeta no qual existimos e cuja vida compartilhamos. Mesmo que Rubem Alves, nas fases mais avançadas de sua obra, não tenha atacado mais consistentemente esses problemas, a forma provocativa de Alves pensar continua sendo um importante recurso para nos ajudar a notar que essas doenças sociais continuam profundamente arraigadas na cultura dominante, sendo legitimadas por diversas formas de linguagem, inclusive os discursos religiosos e acadêmicos. Discursos legitimadores informam as estruturas sociais que criamos sem que notemos sua influência. Dado o modo profundo como afetam a psique humana, eles precisam ser enfrentados num nível onde ação e beleza se encontrem para a produção de novas visões.

Nesse artigo, apresentamos ainda Shaull e Alves como pensadores diferentes, mas que se complementam. Quando em Princeton, eles formaram um duo dinâmico, atraindo o interesse e a imaginação de jovens estudantes que lotaram suas classes. Quem sabe, um exame mais atento das semelhanças e complementaridades das obras desse duo possa nos fornecer novos insights, através dos quais a voz poética de Rubem Alves e a persistência profética de Richard Shaull se juntem para nos ajudar a reimaginar de forma ousada e criativa nossos sonhos e esperanças na construção de um outro mundo possível.

\footnotetext{
6llbid., 24.

62Braz, Ludek, "Alves' s Programmeof Radical Utopianism," Communia Viatarum, XV, No. 4 (1972), 201-209.
} 